\title{
EVALUATION OF WASTE MANAGEMENT PRACTICES AT THE FEDERAL UNIVERSITY OF TECHNOLOGY, OWERRI (FUTO), IMO STATE OF NIGERIA
}

\author{
${ }^{1}$ Nwosu, Oluchi Ulunma; ${ }^{1} *$ Orji, Chimaroke Gabriel; ${ }^{2}$ Nwachukwu, Chioma Success; \\ ${ }^{3}$ Oragba, Chukwuebuka Henry; ${ }^{3}$ Asoegwu, Chisom Rachael; ${ }^{3}$ Awuchi, Chibueze Gospel \\ ${ }^{1}$ Department of Agriculture/Bioenvironmental Engineering, Imo State Polytechnic, \\ Umuagwo, Imo State, Nigeria. \\ ${ }^{2}$ National Environmental Standard and Regulations Enforcement Agency (NESREA) \\ ${ }^{3}$ Department of Environmental Management, Federal University of Technology, Owerri, Imo \\ State, Nigeria.
}

\begin{abstract}
The main purpose of this work was to evaluate the waste management practices at the Federal University of Technology, Owerri (FUTO). The research utilized library, observations and sample survey technique. Other related literatures were also reviewed. Questionnaires based on formulated hypotheses were also employed. Data gathered were analyzed using textual, diagrams (charts and graphs) and tabular forms of data presentation. Percentages and figures were also used to clarify the relationships between variables. Consequently, the findings gotten from the field shows that the kind of domestic solid wastes that is generated in the study area were majorly organic, paper, plastic, metal and textile wastes. About $72 \%$ of all the domestic solid wastes that is generated at the eateries in the study area were mainly organic wastes. The domestic solid waste management strategies in place were burning, open dumping and burying. Open dumping was found to be the most common domestic solid waste management strategy practiced in the study area. The key players involved in the management of solid wastes were the school management and individual households. This study shows that the method of waste management adopted in the study area does not conform to sustainable waste management strategy which results in environmental degradation and health risks. This implies that much attention has not been given to domestic solid waste management in the study area. The study therefore suggests that there is need to introduce solid waste management in the coursework of all the departments in the institution so that they could be informed on the need to maintain a clean and healthy environment. And more attention should be given to waste disposal management through adequate funding by providing the students and residents with properly designed waste disposal points in order to protect the environment from pollution.
\end{abstract}

Key words: Waste Management, Pollution, Environmental Degradation and Open Dumping. 
1.0.

INTRODUCTION

According to Michael (2012), wastes are residual materials which are as a result of human activities which cannot be reused or recovered as a resource, recycled into material production processes thermally/biologically utilized for energy production. Waste streams vary from country to country and may be aggregated as solid, liquid and gaseous wastes; hazardous and nonhazardous wastes or as industrial, commercial, residential or institutional waste streams (Maclaren 2000, UNEP 2005). Today, institutions around the world are producing both toxic and nontoxic waste at unprecedented rate. For instance, in 2012 the municipal solid waste generation levels were 1.3 billion tonnes per year and are expected to rise to approximately 2.2 billion tonnes per annum in 2025, which represents a significant increase in per capita waste generation rates from $1.2 \mathrm{~kg}$ to $1.42 \mathrm{~kg}$ per person per day (World Bank, 2012). Hence, it is inevitable that this waste is prudently managed. Traditionally, waste management has been the responsibility of local governments. However, with the increasing rate of solid waste generation, and awareness and regulations (for recycling and recovery, management and source reduction by intervening at production and consumption level), various institutions have got involved into one or more aspects of solid waste management chain.

Waste management is a global environmental challenging issue that is severe especially in developing countries where increased urbanization, poor planning and lack of adequate resources contribute to the poor state of Municipal Solid waste management (Mwanthi et al., 1997). Proper management of solid waste has been established to be critical to the health and well being of urban residents (World Bank, 2001).

Aliyu (2010) classified wastes into three basic types; solid, liquid and gaseous which could be biodegradable, semi biodegradable and non-biodegradable. The Federal Ministry of Environment (2012), divided urban solid wastes into three main categories; Municipal solid wastes which comprise domestic waste, trade and commercial refuse (from schools, hospitals and clinics) and street cleansing waste; industrial wastes, consisting of refuse generated from industrial operations and by solidification of liquid and gaseous effluents and building construction wastes, which are mainly inert from demolition, excavation and construction activities. Waste management, according to Wokekoro, (2007) as cited by Uchegbu, (1998), in all its ramifications, is a planned system of effectively controlling the production, storage, collection, transportation, processing and disposal or utilization of wastes, in a sanitary, aesthetically acceptable and economical manner. It includes all administrative, financial, legal and planning functions as well as the physical aspects of waste handling.

Folz (2004) indicates that the type of service which various institutional waste managers provide may be categorised into two broad areas: direct waste management related services and support services. The direct waste management related services primarily deal with the provision of services for different stages of waste management chain i.e. collection, transportation, pre-treatment, recycling/recovery and disposal. The support service category deals with the provision of services which indirectly enhance the effectiveness and efficiency of waste management and include and include awareness creation, provision of information, technical expertise as well as financing.

As far as waste management practices are concerned, the key global practices include: source reduction; product reuse; product recycling; waste collection; waste composting; waste 
incineration as well as landfilling/dumping (World Bank, 2012). Each of the waste management practices poses challenges (apart from source reduction which is regarded as ideal). For instance, waste incineration is expensive and contributes to air pollution as well as greenhouse gas emissions. There is also the challenge of disposing of ash. Landfills require land and as susceptible to opposition from potential neighboring populations. Waste collection vehicles contribute significantly to air pollution (Agwu 2012; World Bank 2012).

There are several legal frameworks governing waste management. The different sectors in waste management such as waste generators, waste transporters and waste recyclers/composters have specific roles to play to achieve efficient waste management (NEMA, 2014).

In Europe, the European Union has developed a common legislation framework regarding institutional waste management and requires all its member states to harmonize their systems with it. The legislation underlines the coexistence of different waste management systems that must achieve the same results in terms of recycling targets, diversion of biodegradable waste from landfills and waste prevention (INE, 2009). The legislation's milestone is that by 2020: waste in European institutions is to be managed as a resource; there should be absolute decline in waste generated per capita in the institutions; and recycling and re-use of waste are to be economically attractive options for public and private institutions in the Union (Scheinberg and Alabaster, 2012).

Waste management problems in Africa are varied and complex with infrastructure, political, technical, social/economic, and organizational/management, regulatory and legal issues and challenges to be addressed. According to Ekere and Mugisha (2009), waste in Africa is typically disposed off without consideration for environmental and human health impacts, leading to its accumulation. Disposal of hazardous and non-hazardous waste without segregation is common practice in Africa. The management of municipal solid waste is the other intractable challenge in recent times and is beyond the capacity of most urban areas to effectively manage it resulting in dumping of waste in undesignated sites. Waste management infrastructure is largely nonexistent in most institutions in Africa. Improvements in infrastructure in key institutions in the continent are urgently needed to combat the severe repercussions of poor waste management (Ogbaji and Kunene, 2008).

\subsection{PURPOSE OF THE FIELD WORK}

The purpose of this fieldwork is to examine the waste management practices at the Federal University of Technology, Owerri (FUTO), and recommend effective strategies for the enhancement of waste management practices in the institution.

\subsection{SCOPE AND DESCRIPTION OF THE STUDY AREA}

The area of study is the Federal University of Technology Owerri (FUTO), which is a Federal Government University located in Owerri West, the capital of Imo State. The University is bounded by the communities of Eziobodo, Umuchima, Ihiagwa and Obinze, in Imo State, Nigeria. It is the Premier Federal University of Technology in the South East and South South parts of Nigeria. The study area is made up of Nine (9) faculties subdivided into various departments and other non-academic structures like student's hostels and eateries. 


\subsection{FIELDWORK PROCEDURES}

The researchers were divided and sent to get data on the general state of waste management at FUTO, the types of waste generated, availability/accessibility of waste bins and their usage and if they are properly labeled, waste disposal and collection processes, waste handlers and waste recycling.

\subsection{RECONNAISSANCE SURVEY}

In view of the objectives of the study, a reconnaissance survey (visual survey) of the study area was carried out to enable the researchers get acquainted with the study area, observe and study the physical characteristics of the area in relation to waste generation, types, mode of collection and disposal. This gave the researchers an insight on various waste management facilities at FUTO.

\subsection{TYPES OF DATA}

The study used both primary data (collected from the field) and secondary data.

\subsubsection{Primary Data}

Primary data were mainly obtained through field observations and interviews. Field observations included all the observations by the researchers on the general state of FUTO, the types of waste generated, availability/accessibility of waste bins and their usage and if they are properly labeled, waste disposal and collection processes, waste handlers and waste recycling. Field interviews were carried out through the administration of 327 questionnaires to some students (excluding first year students) and staffs of the institution. The questionnaires focused on the types of waste generated by the University and disposal methods; awareness in waste management practices as well as the challenges of managing waste at FUTO.

\subsubsection{Secondary Data}

The secondary data was obtained from books, journals, published and unpublished texts, documents, magazines, conference articles, government ministries and agencies such as the N.P.C. for population and household Census of 2006, National Bureau of Statistics and related websites.

\subsection{SAMPLING SIZE AND SAMPLING TECHNIQUES}

The questionnaire was drafted to provide required responses from target population to obtain data in critical areas of waste management in the in the study area to provide answers to the research questions, and was distributed randomly to some none first year students and staffs from various departments of different faculties of the Federal University of Technology, Owerri. These levels of students were chosen because they have been in the school long enough and had familiarized with the school environment and therefore knew where most of the sanitation facilities are located. To determine the sample size for this fieldwork, Krejcie and Morgan's (1970) method of determining sample size was used which states that: for an area with a population between 2000-2200, the sample size to be used is 327 . Thus, a total number of three hundred and twenty seven (327) respondents in the study area were sampled with the view of analyzing the waste management strategies in the study area. 


\subsection{INSTRUMENTS FOR DATA COLLECTION}

i. Digital Samsung camera for taking photographs, especially open dump sites in the study area.

ii. Structured questionnaire for subject responses

\subsection{METHOD OF DATA ANALYSIS}

Data were subjected to analysis using descriptive statistics like Percentage distribution and charts for quantitative data.

Data obtained were also presented in tables and charts. The information obtained from the questionnaire was processed and distributed in Tables to facilitate a clear and concise view and understanding. Population data obtained from the faculty and information obtained from the medical practitioners in the clinic was also presented in tabular form. Photographs of different waste management systems were also presented.

\subsection{PRESENTATION AND ANALYSIS OF DATA 6.1. INTRODUCTION}

This section provides a summary of the results obtained from the administration of questionnaires in order to analyze the waste management strategies in the study area. It includes a summary of the demographic and socio economic characteristics of the respondents, types of wastes generated in the study area, waste management strategies employed in the study area, key players in domestic waste management in the study area and effectiveness of the waste management strategies employed in the study area.

\subsection{DEMOGRAPHIC AND SOCIO ECONOMIC CHARACTERISTICS OF RESPONDENTS}

\subsubsection{Sex Distribution of the Respondents}

The data gotten from the field is shown in table 1 below. From the table, $53.2 \%$ of the respondents are males while $46.8 \%$ are females. This pattern could be traced in part to social and religious factor as a result of less dominant role performed by women. According to Jiggins (1994) women's perspectives and values for the environment are somewhat different than men's. Women give greater priority to protection of and improving the capacity of nature. Dankelman and Davidson (1998) also observed that women play a key role in managing their natural surroundings and adopt several mechanisms to deal with the kinds of environmental crisis they face. 
Table 1: Sex Distribution of the Respondents

\begin{tabular}{lccc}
\hline Area & Male & Female & Total \\
\hline SOET & 34 & 57 & $\mathbf{9 1}$ \\
SEET & 36 & 27 & $\mathbf{6 3}$ \\
SOHT & 11 & 4 & $\mathbf{1 5}$ \\
SAAT & 21 & 8 & $\mathbf{2 9}$ \\
SMAT & 16 & 3 & $\mathbf{1 9}$ \\
SOPT & 19 & 8 & $\mathbf{2 7}$ \\
SCIT & 6 & 11 & $\mathbf{1 7}$ \\
SOBS & 11 & 7 & $\mathbf{1 8}$ \\
SBMS & 5 & 10 & $\mathbf{1 5}$ \\
HOSTEL A (Male) & 12 & 0 & $\mathbf{1 2}$ \\
HOSTEL C (Female) & 0 & 12 & $\mathbf{1 2}$ \\
EATERIES & 3 & 6 & $\mathbf{9}$ \\
\hline TOTAL & $\mathbf{1 7 4}$ & $\mathbf{1 5 3}$ & $\mathbf{3 2 7}$ \\
\hline PERCENTAGE\% & $\mathbf{5 3 . 2}$ & $\mathbf{4 6 . 8}$ & $\mathbf{1 0 0}$ \\
\hline SOUTC: Researchers FieldwOrk & & & \\
\hline
\end{tabular}

Source: Researchers Fieldwork Survey, 2019.

\subsubsection{Age Distribution of the Respondents}

Table 2 below shows the age distribution of the respondents. This showed that $8 \%$ were less than twenty years of age, $22.3 \%, 39.1 \%, 23.5 \%$ and $7.0 \%$ were between $21-25,26-30,31-35$ and above 35 years of age respectively. This showed that majority of the respondents (about $92 \%$ ) were above 20 years of age and were able to provide the information necessary for the study.

Table 2: Age Distribution of the Respondents

\begin{tabular}{lcccccc}
\hline Area & $\begin{array}{c}<\mathbf{2 0} \\
\text { Years }\end{array}$ & $\begin{array}{c}\mathbf{2 1}-\mathbf{2 5} \\
\text { Years }\end{array}$ & $\begin{array}{c}\mathbf{2 6} \mathbf{- 3 0} \\
\text { Years }\end{array}$ & $\begin{array}{c}\mathbf{3 1}-\mathbf{3 5} \\
\text { Years }\end{array}$ & $\begin{array}{c}>35 \\
\text { Years }\end{array}$ & Total \\
\hline SOET & 4 & 43 & 10 & 5 & 3 & $\mathbf{6 5}$ \\
SEET & 6 & 23 & 7 & 10 & 2 & $\mathbf{4 8}$ \\
SOHT & 1 & 6 & 9 & 0 & 0 & $\mathbf{1 6}$ \\
SAAT & 2 & 5 & 7 & 10 & 3 & $\mathbf{2 7}$ \\
SMAT & 1 & 6 & 8 & 7 & 2 & $\mathbf{2 4}$ \\
SOPT & 5 & 9 & 5 & 1 & 2 & $\mathbf{2 2}$ \\
SCIT & 0 & 6 & 6 & 1 & 4 & $\mathbf{1 7}$ \\
SOBS & 3 & 12 & 2 & 12 & 0 & $\mathbf{2 9}$ \\
SBMS & 0 & 3 & 7 & 11 & 2 & $\mathbf{2 3}$ \\
HOSTEL A (Male) & 3 & 5 & 1 & 8 & 1 & $\mathbf{1 8}$ \\
HOSTEL C (Female) & 1 & 2 & 4 & 5 & 2 & $\mathbf{1 4}$ \\
EATERIES & 0 & 8 & 7 & 7 & 2 & $\mathbf{2 4}$ \\
\hline TOTAL & $\mathbf{2 6}$ & $\mathbf{1 2 8}$ & $\mathbf{7 3}$ & $\mathbf{7 7}$ & $\mathbf{2 3}$ & $\mathbf{3 2 7}$ \\
\hline PERCENTAGE\% & $\mathbf{7 . 9 5}$ & $\mathbf{3 9 . 2}$ & $\mathbf{2 2 . 3}$ & $\mathbf{2 3 . 5}$ & $\mathbf{7 . 0 5}$ & $\mathbf{1 0 0}$ \\
\hline
\end{tabular}

Source: Researchers Fieldwork Survey, 2019.

\subsubsection{Educational/Academic Level of the Respondents}

The data on the educational/academic level is presented in table 3. The data shows that the respondents who have other educational qualifications or are above 500Level in the 
institution constitute 5.8\% while the respondents who are within 200Level and 500Level in the institution constitute $94.2 \%$.

Table 3: Educational/Academic Level of the Respondents.

\begin{tabular}{lcccccc}
\hline Area & $\begin{array}{c}\mathbf{2 0 0} \\
\text { Level }\end{array}$ & $\begin{array}{c}\mathbf{3 0 0} \\
\text { Level }\end{array}$ & $\begin{array}{c}\mathbf{4 0 0} \\
\text { Level }\end{array}$ & $\begin{array}{c}\mathbf{5 0 0} \\
\text { Level }\end{array}$ & Others & Total \\
\hline SOET & 8 & 9 & 7 & 16 & 3 & $\mathbf{4 3}$ \\
SEET & 2 & 7 & 8 & 13 & 2 & $\mathbf{3 2}$ \\
SOHT & 3 & 4 & 10 & 8 & 0 & $\mathbf{2 5}$ \\
SAAT & 5 & 7 & 5 & 14 & 2 & $\mathbf{3 3}$ \\
SMAT & 1 & 6 & 7 & 19 & 0 & $\mathbf{3 3}$ \\
SOPT & 3 & 11 & 7 & 8 & 2 & $\mathbf{3 1}$ \\
SCIT & 5 & 8 & 0 & 2 & 2 & $\mathbf{1 7}$ \\
SOBS & 2 & 3 & 9 & 4 & 0 & $\mathbf{1 8}$ \\
SBMS & 4 & 4 & 3 & 7 & 1 & $\mathbf{1 9}$ \\
HOSTEL A (Male) & 5 & 5 & 8 & 9 & 2 & $\mathbf{2 9}$ \\
HOSTEL C (Female) & 7 & 1 & 7 & 5 & 1 & $\mathbf{2 1}$ \\
EATERIES & 3 & 5 & 11 & 3 & 4 & $\mathbf{2 6}$ \\
\hline TOTAL & $\mathbf{4 8}$ & $\mathbf{7 0}$ & $\mathbf{8 2}$ & $\mathbf{1 0 8}$ & $\mathbf{1 9}$ & $\mathbf{3 2 7}$ \\
\hline PERCENTAGE\% & $\mathbf{1 4 . 7}$ & $\mathbf{2 1 . 4}$ & $\mathbf{2 5 . 1}$ & $\mathbf{3 3 . 0}$ & $\mathbf{5 . 8 0}$ & $\mathbf{1 0 0}$ \\
\hline
\end{tabular}

Source: Researchers Fieldwork Survey, 2019.

This shows that the level of literacy in the study area is high due to the study area is a higher institution of learning and the migration of educated people in search of employment opportunities or higher academic qualifications could have a positive impact on their perception of waste and its management.

\subsection{DOMESTIC SOLID WASTE MANAGEMENT STRATEGIES EMPLOYED IN THE STUDY AREA}

Table 4 below shows the results on the various strategies employed in the study area for waste management. The information shows that the major domestic waste management strategies employed in the study area are open dumping, burning (see picture 1 and 2) and burying. About $61.2 \%$ of the respondents dump their wastes openly; about $22.0 \%$ bury their wastes while about $16.2 \%$ burn their wastes. Efe (2010) in the same vein reported that there were no authorized dumpsites in within Ihiagwa and Eziobodo Community, which makes the major methods of waste disposal open dumping, land filling and dig and bury. 
Table 4: Types of Domestic Solid Waste Management Strategies in the Study Area

\begin{tabular}{lccccc}
\hline Area & Burning & Burying & $\begin{array}{c}\text { Open } \\
\text { Dumping }\end{array}$ & Others & Total \\
\hline SOET & 8 & 11 & 19 & 0 & $\mathbf{3 8}$ \\
SEET & 2 & 3 & 36 & 0 & $\mathbf{4 1}$ \\
SOHT & 3 & 4 & 10 & 1 & $\mathbf{1 8}$ \\
SAAT & 5 & 2 & 21 & 0 & $\mathbf{2 8}$ \\
SMAT & 3 & 4 & 20 & 1 & $\mathbf{2 8}$ \\
SOPT & 3 & 8 & 10 & 0 & $\mathbf{2 1}$ \\
SCIT & 9 & 7 & 5 & 0 & $\mathbf{2 1}$ \\
SOBS & 2 & 8 & 4 & 0 & $\mathbf{1 4}$ \\
SBMS & 5 & 6 & 7 & 0 & $\mathbf{1 8}$ \\
HOSTEL A (Male) & 6 & 5 & 25 & 0 & $\mathbf{3 6}$ \\
HOSTEL C (Female) & 2 & 9 & 30 & 0 & $\mathbf{4 1}$ \\
EATERIES & 4 & 5 & 13 & 0 & $\mathbf{2 2}$ \\
\hline TOTAL & $\mathbf{5 3}$ & $\mathbf{7 2}$ & $\mathbf{2 0 0}$ & $\mathbf{2}$ & $\mathbf{3 2 7}$ \\
\hline PERCENTAGE\% & $\mathbf{1 6 . 2}$ & $\mathbf{2 2 . 0}$ & $\mathbf{6 1 . 2}$ & $\mathbf{0 . 6 0}$ & $\mathbf{1 0 0}$ \\
\hline
\end{tabular}

Source: Researchers Fieldwork Survey, 2019.

This is an indication that most people within Federal University of Technology, Owerri the study area dump their wastes on any available open space. Open dumping could be a source of health problems for the students, staffs and residents of the institution, and can obstruct free flow of drainage especially when dumped in drainage parts, which may lead to flooding due to blockage of gutters and other water channels during the rainy season.
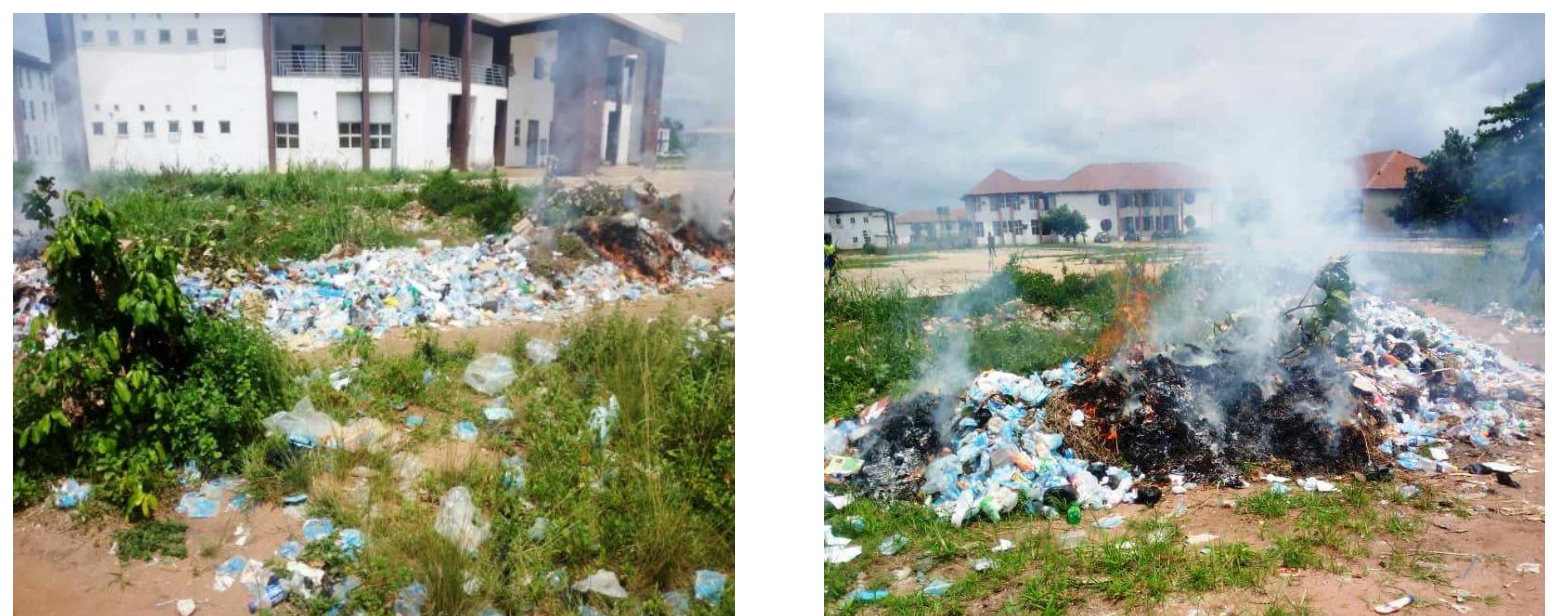

Picture 1: Open dumping of waste beside SOES Building

Picture 2: Burning of waste dump openly behind Public Procurement Building 

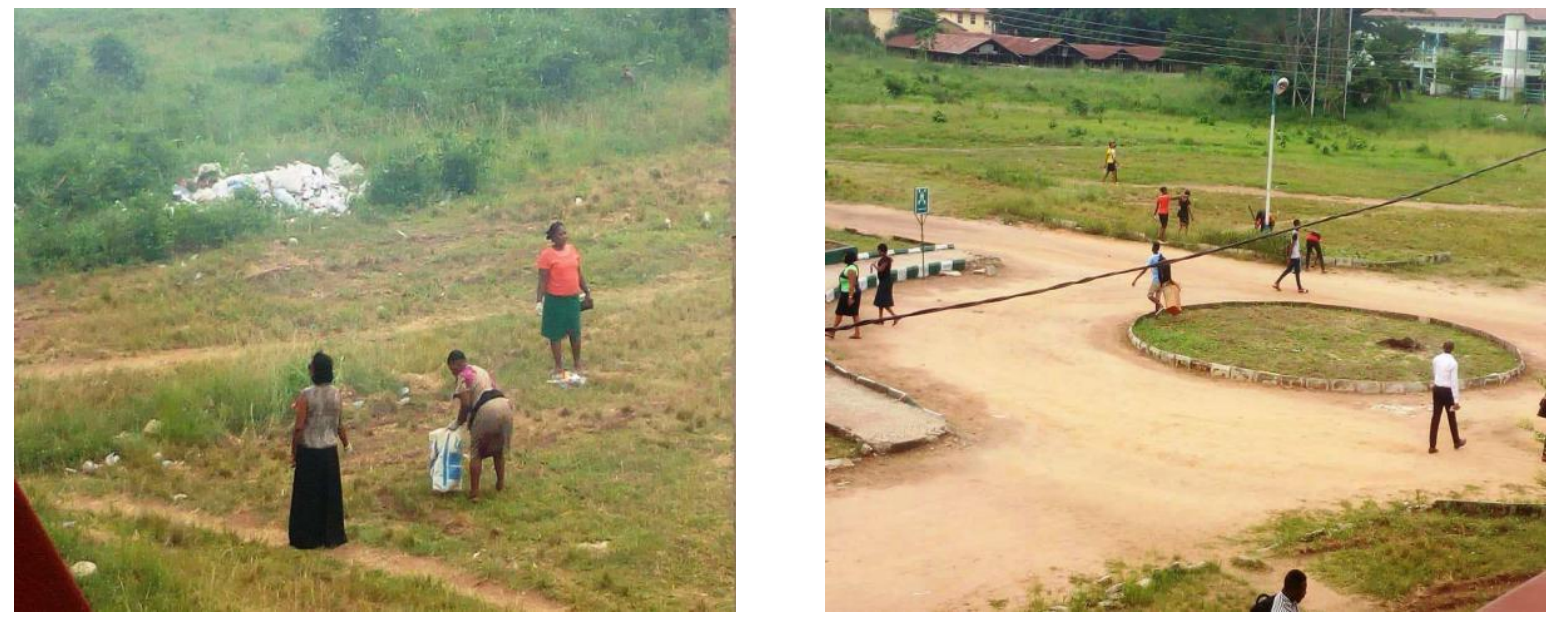

Picture 3: Sanitation exercise going on in front of the Department of Environmental Management.

Picture 4: Sanitation exercise going on at the School of Health Technology.

It was observed in some faculties that operate with waste bin and basket such as School of Environmental Management that their final disposing point is at the back of the Faculty building.
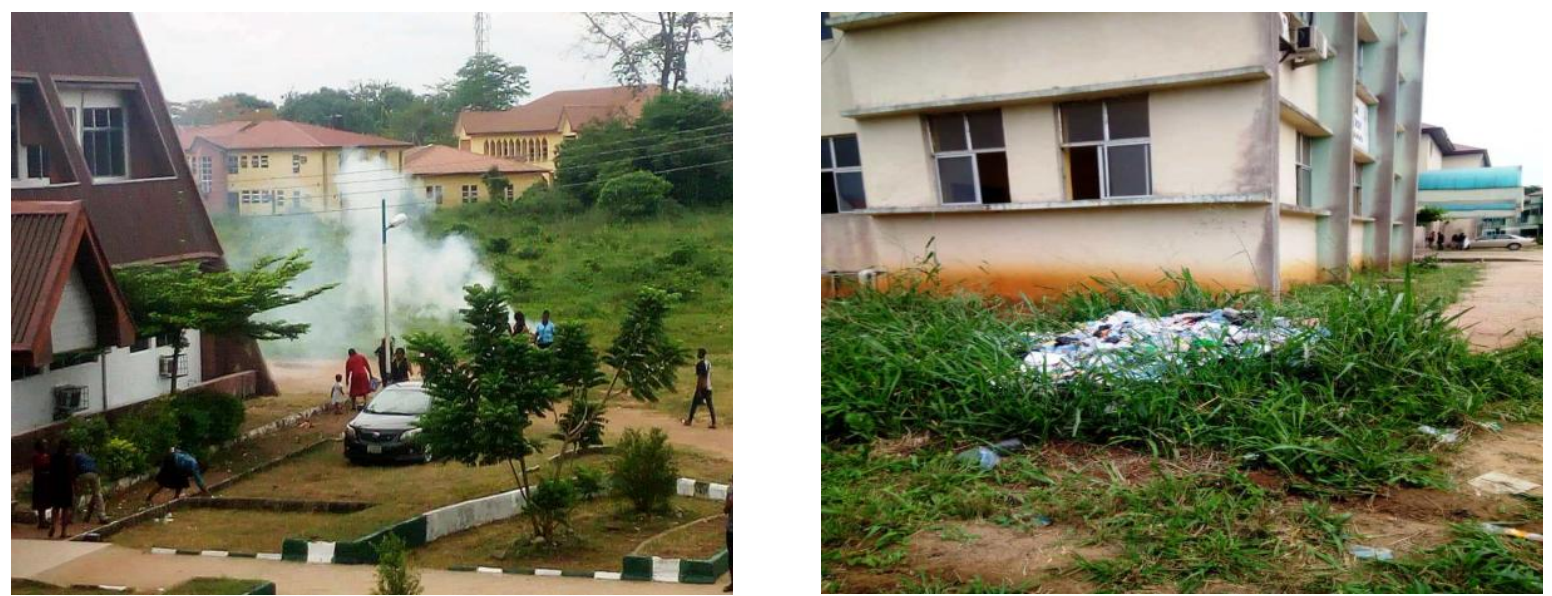

Picture 5: Burning of waste-dump beside School of Management Technology.

Picture 6: Waste dumped behind School of Agriculture and Agricultural Technology.

In order to get firsthand information on the waste management practices within the study area, to complement with the responses from the respondents, the group members launched a reconnaissance move around the University to obtain information through direct observation. We investigated the method of waste collection around the University, and it was observed that only few faculties of the university operates with waste bins and baskets for waste collection, and while the majority practice open dumping and burning of wastes. 


\subsection{KEY PLAYERS IN DOMESTIC SOLID WASTE MANAGEMENT IN THE STUDY AREA}

In order to achieve the third objective of the study, the results on the Key Players in domestic solid waste management in the study area is shown in the Figure 6.1 below.

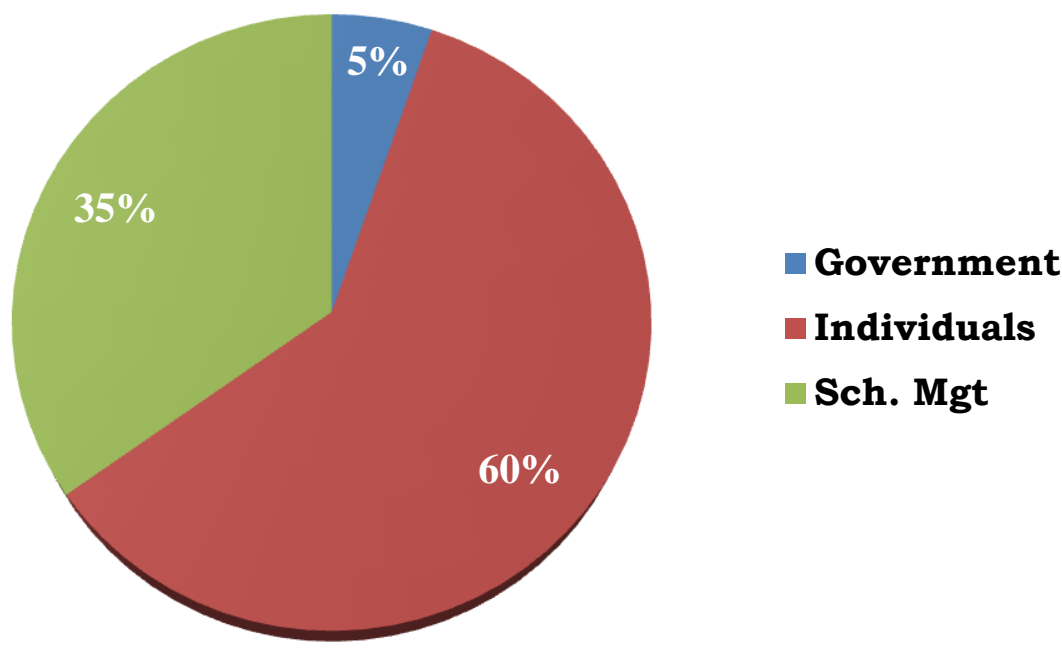

Figure 6.1: Pie Chart Showing Key Players in the Domestic Solid Waste Management in the Study.

From the chart above, 5\% of the respondents reported that the government plays the key role in managing waste in the study area through the Imo State Environmental Protection Agency (IMOSEPA) while $60 \%$ of the respondents reported that individual play the key role in managing the waste they generated in the study area through different avenues like the use of waste bins/buckets and wheel barrows, while $35 \%$ of the respondents reported that the School Management plays the key role in managing waste generated in the study area. Scavengers also operate in the study area, picking recyclable materials as they are thrown away. Agunwamba (2003), noted that this group of scavengers is also largely made up of uneducated young men who commute daily from neighboring slums and satellite towns to dumpsites and are more organized, as their activities are regulated by the leadership of their association. 


\subsection{THE EFFECTIVE LEVELS OF THE DOMESTIC SOLID WASTE MANAGEMENT STRATEGIES IN THE STUDY AREA}

In order to achieve the fourth objective of the study, the responses on the assessment of the domestic solid waste management strategies in the study area is discussed below.

Table 5: Respondents' Assessment of Burning as a Domestic Solid Waste Management Strategy

\begin{tabular}{lcccccc}
\hline \multirow{2}{*}{ Area } & \multicolumn{2}{c}{ Not Effective } & \multicolumn{2}{c}{ Effective } & \multicolumn{2}{c}{ Very Effective } \\
\cline { 2 - 7 } & Frequency & $\begin{array}{c}\text { Percentage } \\
\text { \% }\end{array}$ & Frequency & $\begin{array}{c}\text { Percentage } \\
\mathbf{\%}\end{array}$ & Frequency & Percentage \\
$\mathbf{\%}$
\end{tabular}

Source: Researchers Fieldwork Survey, 2019.

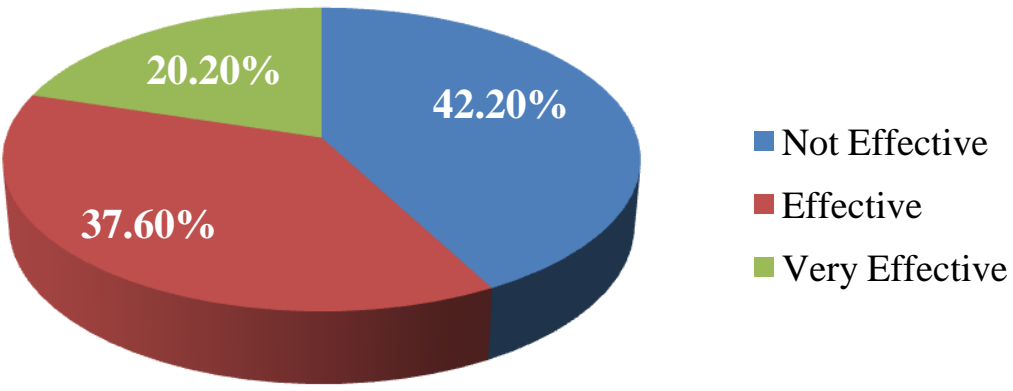

Figure 6.2: Pie Chart Showing the Respondents' Assessment of Burning as a Domestic Solid Waste Management Strategy

The response on the assessment of burning as a domestic solid waste management strategy in the study area is shown in table 5 above. The assessment shows that about $42 \%$ of the respondents reported that burning of waste is not effective while about $38 \%$ and $20 \%$ reported that burning of waste is effective and very effective in the study area. The result shows that the majority of the respondents are not aware of the health implication of burning domestic solid wastes in the study area. Burning causes air pollution; it increases the concentration of carbon (IV) oxide and contributes to global warming. 


\subsection{RESPONDENTS' ASSESSMENT OF BURYING AS A DOMESTIC SOLID WASTE MANAGEMENT STRATEGY}

Table 6. Below shows the response on the assessment of burning as a domestic solid waste management strategy in the study area.

Table 6: Respondents' Assessment of Burying as a Domestic Solid Waste Management Strategy

\begin{tabular}{lcccccc}
\hline Area & \multicolumn{2}{c}{ Not Effective } & \multicolumn{2}{c}{ Effective } & \multicolumn{2}{c}{ Very Effective } \\
\cline { 2 - 7 } & Frequency & $\begin{array}{c}\text { Percentage } \\
\mathbf{\%}\end{array}$ & Frequency & $\begin{array}{c}\text { Percentage } \\
\mathbf{\%}\end{array}$ & Frequency & $\begin{array}{l}\text { Percentage } \\
\mathbf{\%}\end{array}$ \\
\hline SOET & 6 & 1.83 & 53 & 16.2 & 23 & 7.03 \\
SEET & 11 & 3.36 & 24 & 7.34 & 11 & 3.36 \\
SOHT & 2 & 0.62 & 10 & 3.06 & 4 & 1.22 \\
SAAT & 7 & 2.14 & 13 & 3.98 & 6 & 1.38 \\
SMAT & 8 & 2.45 & 14 & 4.28 & 6 & 1.38 \\
SOPT & 3 & 0.92 & 11 & 3.36 & 10 & 3.06 \\
SCIT & 2 & 0.61 & 13 & 3.98 & 2 & 0.61 \\
SOBS & 1 & 0.31 & 12 & 3.67 & 5 & 1.53 \\
SBMS & 1 & 0.31 & 9 & 2.75 & 2 & 0.61 \\
HOSTEL A & 4 & 1.22 & 6 & 1.38 & 8 & 2.45 \\
(Male) & & & & & & \\
HOSTEL & 3 & 0.92 & 8 & 2.45 & 4 & 1.22 \\
(Female) & 2 & 0.61 & 11 & 3.36 & 6 & 1.38 \\
EATERIES & $\mathbf{5 0}$ & $\mathbf{1 5 . 3}$ & $\mathbf{1 8 4}$ & $\mathbf{5 6 . 3}$ & $\mathbf{9 3}$ & $\mathbf{2 8 . 4}$ \\
\hline TOTAL & & & & & &
\end{tabular}

Source: Researchers Fieldwork Survey, 2019.

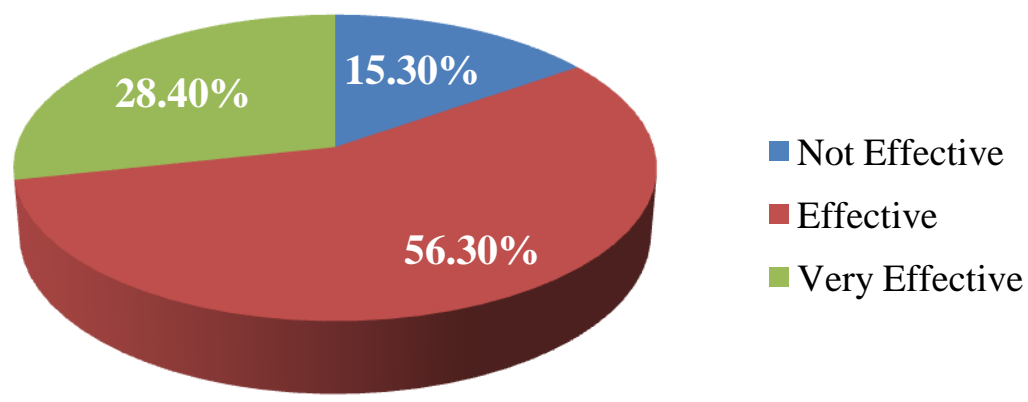

Figure 6.3: Pie Chart Showing the Respondents' Assessment of Burying as a Domestic Solid Waste Management Strategy.

The table shows that 50 respondents (about 15\%) are of the view that burying of domestic solid waste is not effective, 184 respondents (about 56\%) think that burying of domestic solid waste is effective while 93 respondents (about 28\%) think that burying of domestic solid 
waste is very effective. This shows that a large percentage of the respondents see burying as an effective method of managing domestic solid waste.

\subsection{RESPONDENTS' ASSESSMENT OF OPEN DUMPING AS A DOMESTIC SOLID WASTE MANAGEMENT STRATEGY}

The table on the respondent's view on open dumping is presented in table 7 below.

Table 7: $\quad$ Assessment of Open Dumping as a Domestic Solid Waste Management Strategy

\begin{tabular}{|c|c|c|c|c|c|c|}
\hline \multirow[b]{2}{*}{ Area } & \multicolumn{2}{|c|}{ Not Effective } & \multicolumn{2}{|c|}{ Effective } & \multicolumn{2}{|c|}{ Very Effective } \\
\hline & Frequency & $\begin{array}{c}\text { Percentage } \\
(\%)\end{array}$ & Frequency & $\begin{array}{c}\text { Percentage } \\
(\%)\end{array}$ & Frequency & $\begin{array}{c}\text { Percentage } \\
(\%)\end{array}$ \\
\hline$\overline{\text { SOET }}$ & 77 & 27.2 & 6 & 1.38 & 2 & 0.61 \\
\hline SEET & 52 & 20.5 & 6 & 1.38 & 1 & 0.31 \\
\hline SOHT & 13 & 3.98 & 3 & 0.92 & 0 & 0 \\
\hline SAAT & 26 & 7.95 & 2 & 0.61 & 1 & 0.31 \\
\hline SMAT & 24 & 7.34 & 3 & 0.92 & 0 & 0 \\
\hline SOPT & 23 & 7.03 & 2 & 0.61 & 2 & 0.61 \\
\hline SCIT & 16 & 4.89 & 1 & 0.31 & 0 & 0 \\
\hline SOBS & 13 & 3.98 & 3 & 0.92 & 2 & 0.61 \\
\hline SBMS & 11 & 3.36 & 1 & 0.31 & 0 & 0 \\
\hline $\begin{array}{l}\text { HOSTEL A } \\
\text { (Male) }\end{array}$ & 10 & 3.06 & 4 & 1.22 & 1 & 0.31 \\
\hline $\begin{array}{l}\text { HOSTEL C } \\
\text { (Female) }\end{array}$ & 12 & 3.67 & 2 & 0.61 & 2 & 0.61 \\
\hline EATERIES & 5 & 1.53 & 1 & 0.31 & 0 & 0 \\
\hline TOTAL & 282 & 86.2 & 34 & 10.4 & 11 & 3.36 \\
\hline
\end{tabular}

Source: Researchers Fieldwork Survey, 2019. 


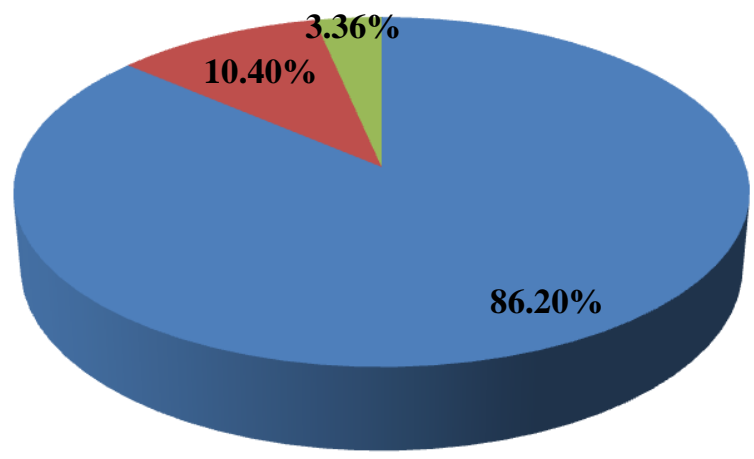

- Not Effective

Effective

Very Effective

\section{Figure 6.4: Pie Chart Showing the Respondents' Assessment of Open Dumping as a Domestic Solid Waste Management Strategy.}

The table shows that about $86 \%$ reported that open dumping is not an effective method of managing domestic solid waste, while about $10 \%$ and $4 \%$ feel that open dumping is effective and very effective in managing domestic solid waste in the study area. This is because open dumping pollutes the environment; it can make roads inaccessible by obstructing the free flow of traffic. It can also lead to flooding due to blockage of gutters and other water channels during the rainy season.

\subsection{SUMMARY OF FINDINGS}

The results gotten from the field show that the kinds of domestic solid wastes generated in the study area were majorly organic, paper, plastic, metal and textile wastes. About $72 \%$ of all the domestic solid wastes generated at the eateries in the study area were mainly organic wastes. The domestic solid waste management strategies in place were burning, open dumping and burying. Open dumping was found to be the most common domestic solid waste management strategy practiced in the study area. The key players involved in the management of solid wastes were the school management and individual households and the rate of waste generation was found to exceed the rate of waste disposal in the study area because the frequency in which the residents generate domestic solid wastes was higher than the frequency in which they dispose the domestic solid wastes generated.

The response on the assessment of burning as a domestic solid waste management strategy in the study area show that $42 \%$ of the respondents feel that burning of domestic solid waste is not effective while about $38 \%$ and $20 \%$ reported that burning of domestic solid waste is effective and very effective in the study area. About $15 \%$ of the respondents feel that burying of domestic solid waste is not effective, about $56 \%$ of the respondents think that burying of domestic solid waste is effective while about $28 \%$ of the respondents think that burying of domestic solid waste is very effective. A very high percentage (about 86\%) of the respondents reported that open dumping is not an effective method of managing domestic solid waste, while about $10 \%$ and $4 \%$ feel that open dumping is effective and very effective in managing domestic solid waste in the study area. 


\subsection{CONCLUSION}

The findings of this study showed that the method of waste management adopted in the study area does not conform to sustainable waste management strategy which results in environmental degradation and health risks. This implies that much attention has not been given to domestic solid waste management in the study area. To ensure a healthy environment, domestic solid wastes need to be properly managed to control or limit pollution; this therefore calls for urgent precautionary measures to protect the population against the adverse impacts of pollutants as well as degradation of the environment. The findings conform to those of Achankeng (2003), who reported that most African countries do not have a firm grip on sustainable method of managing solid waste.

\subsection{RECOMMENDATIONS}

Based on the findings of this study the following recommendations have been put forward.

i. The first thing that needs urgent attention is in the area of public enlightenment and environmental and health education. Without grassroots environmental education and enlightenment, enforcement of environmental sanitation and waste disposal laws has a very little prospect of success. The public needs to be enlightened on proper waste generation and disposal practices including sorting of wastes. This can be achieved through enlightenment campaign through wall posters and chats, to educate the students, staffs and other residents on the implications of inappropriate waste disposal.

ii. There is also a need to introduce solid waste management in the course work of all the departments in the institution so that they could be informed on the need to maintain a clean and healthy environment.

iii. More attention should be given to waste disposal management through adequate funding by providing the students and residents with properly designed waste disposal points in order to protect the environment from pollution. As a short term measure, there is a need to upgrade existing facilities at major open dumpsites in the University by providing access roads, security fencing, temporary shelters and other utilities to make for a better environment (Festus and Ogoegbunam, 2012).

iv. The Imo State Environmental Protection Agency through the School management should advise the students and other residents to separate domestic solid wastes at source, this helps to reduce the time used in sorting at the wastes disposal and recycling site.

v. Composting as a method of waste management should be adopted since majority of the domestic solid waste generated in the eateries is organic in nature. In addition, the use of organic fertilizers should be promoted in the state and country at large. 


\section{REFERENCES}

Achankeng, E. (2003). Globalization, Urbanization and Municipal Solid Waste Management in Africa. Africa on a Global Stage: 1-22.

Agunwamba, J. C. (2003) Analysis of scavengers' activities and recycling in some cities of Nigeria. Environmental Management, 32(1), pp.116-127

Agwu, L (2012). Waste collection multi objective model with real time traceability data. Journal of Waste Management 31, 2391-2405

Aliyu, B.N. (2010). An Analysis of Municipal Solid Waste in Kano Metropolis, Nigeria. Journal of Human Ecology. 31(2): 111-119

Ekere, W. and Mugisha, J. (2009). Factors influencing waste separation and utilization among households in the Lake Victoria crescent, Uganda. Journal ofWaste Management, 29, 3047-3051

Festus, M.O. and Ogegbunam A. (2012). Imperatives of Environmental Education and Awareness Creation to Solid Waste Management in Nigeria. Educational Sciences $3(2)$.

Folz, D.H., (2004). Service quality and benchmarking the performance of municipal services. Public Administration Review. 64 (2), 209-220.

INE (2009). The Spanish Waste Sector: Waste Collection, Transport and Treatment. Dolores Dizy Menéndez \& Olga Ruiz Cañete.Ciriec N 2010/03 Issn 2070- 8289, Instituo Nacional De Estadística

Maclaren, Y. (2000). Improvement and modification of the routing system for the health-care waste collection and transportation in Istanbul. Journal of Waste Management 28, 1461-1471.

Michael-Agwuoke, M. U. (2012). Is waste-to-energy changing the definition of waste? presented at the 3rd International chemical and environment conference ICEEC 2012, Kuala Lumpur, Malaysia, 21-23 December, 2012

Mwanthi, M.A. \& Nyabola, L.O. (1997). Solid Waste Management in Nairobi City: Knowledge and Altitudes. Environmental Health, 12: 23-29.

Ogbaji, T., and Kunene, H., (2008). Towards zero waste in emerging countries - An African experience. Journal of Waste Management 2(8), 1480-1492.

Scheinberg, A., and, C., A. Alabaster, G. (2012) Comparative analysis of solid wastemanagement in 20 cities. Waste Management \& Research, 30(3) 237-254

United Nation Environmental programme, (2005). Solid Waste Management: Volume 1, Calrecover Incorporation.

Wokekoro, E. (2007). Solid Waste Management in the Construction Industry (A Case Study of Port Harcourt Metropolis). Waste Management, Environmental Geotechnology and Global Sustainable Development, 20: 1-11

World Bank (2001). Philippines Environment Monitor 2001: Solid Waste. The World Report Paper, No.234/12.

World Bank, (2012). What a Waste: A Global Review of Solid Waste Management Urban Development Series Knowledge Papers. (Accessed 09.05.19) 


\section{ABBREVIATIONS}

FUTO - Federal University of Technology, Owerri.

SOET - School of Environmental Technology.

SEET - School of Engineering and Engineering Technology

SOHT - School of Health Technology.

SMAT - School of Management Technology.

SOPS - School of Physical Sciences.

SCIT - School of Computing and Information Technology.

SAAT - School of Agricultural and Agricultural Technology.

SOBS - School of Biological Sciences

SBMS - School of Basic Medical Sciences

UNICEF - United Nations Children Education Fund.

WHO - World Health Organization.

IMOSEPA - Imo State Environmental Protection Agency 